\title{
PEROXIDASE (POD) AND POLYPHENOLOXIDASE (PPO) IN GRAPE (Vitis vinifera $\mathrm{L}$.)
}

\author{
ESTELA DE PIERI TROIANI ${ }^{1}$ \\ CLARIZA TOMÉ TROPIANI ${ }^{1}$ \\ EDMAR CLEMENTE ${ }^{2}$
}

\begin{abstract}
The enzimatic activity of peroxidase (POD) and polyphenoloxidase (PPO) extracted from three grape cultivars (Vitis vinifera L.), cultivated in Marialva city, state of Paraná, was evaluated in this study. The enzymatic extracts were prepared starting from the Rubi, Borbon and Benitaka grape cultivars pulp and peel. The activity of the peroxidase was 53.00 units $/ 100 \mathrm{~g}$ in the extract from the Rubi cultivar peel, and 327.00 units $/ 100 \mathrm{~g}$ from the Benitaka cultivar, these values being superior to those observed in the same cultivars pulp extracts, which were 7.67 units/100 $\mathrm{g}$ and 44.00 units/100 g respectively. However, the result was opposite in the Borbon cultivar, with values of 141.11 units/100 $\mathrm{g}$ in the pulp and 11.50 units/100 $\mathrm{g}$ in the peel being found. The results of the polyphenoloxidase in the Borbon cultivar activity were 100.18 units $/ 100 \mathrm{~g}$ in the pulp and 102.60 units/100 $\mathrm{g}$ in the peel, and in the Rubi
\end{abstract}

and Benitaka cultivars were 60.40 units/100 g, 48.62 units/100 $\mathrm{g}$ in the pulp and 17.40 units/100 g, and 26.20 units/100 $\mathrm{g}$ in the peel, respectively. Protein determination was carried out in each extract, and the results found in the pulp and peel, respectively, were 0.56 and $0.64 \mathrm{mg} / 100 \mathrm{~g}$ for cultivar Benitaka, 1.38 and $6.45 \mathrm{mg} / 100 \mathrm{~g}$ for cultivar Rubi, and 21.38 and $5.68 \mathrm{mg} / 100 \mathrm{~g}$ for Borbon. The extracts were submitted to thermal treatments $\left(60^{\circ} \mathrm{C}, 65^{\circ} \mathrm{C}\right.$, $70^{\circ} \mathrm{C}$ and $75^{\circ} \mathrm{C}$ for a 1 to 10 minutes period) to observe the behavior of the peroxidase and polyphenoloxidase enzymatic activity, being verified a continuous decrease of the peroxidase and polyphenoloxidase activities as a result of the thermal treatment. The extracts of the Rubi and Benitaka cultivars were more heat stable than the extract from the Borbon cultivar for both enzymes. However, the temperatures used were not enough for a total inactivation of the enzymes.

INDEX TERMS: Peroxidase, polyphenoloxidase, activity, grape, Vitis vinifera.

\section{PEROXIDASE (POD) E POLIFENOLOXIDASE (PPO) EM UVA (Vitis vinifera $\mathrm{L}$.)}

\begin{abstract}
RESUMO - Neste trabalho, estudou-se a atividade enzimática da peroxidase (POD) e da polifenoloxidase (PPO) extraídas de três cultivares de uvas (Vitis vinifera L.) cultivadas em Marialva, PR. Os extratos enzimáticos foram preparados a partir da polpa e da casca das cultivares de uvas Rubi, Borbon e Benitaka. A atividade da peroxidase foi de 53,00 unid./100 g no extrato da casca da cultivar Rubi, e da cultivar Benitaka foi de 327,00 unid./100 g, valores esses superiores aos encontrados nos extratos da polpa das mesmas cultivares, que foram de 7,67 unid./100 g e 44,00 unid/100 g, respectivamente. Porém, na cultivar Borbon, o resultado observado foi inverso, mostrando para o extrato da polpa 141,11 unid./100 g e para o extrato da casca, 11,50 unid./100 g. O resultado da atividade da polifenoloxidase na cultivar Borbon foi de 100,18 unid./100 g; na polpa e na casca, 102,60 unid./100 g, e na cultivar Ru-
\end{abstract}

bi e Benitaka foram 60,40 unid./100 g, 48,62 unid./100 g na polpa e 17,40 unid./100 g, 26,20 unid./100 g na casca, respectivamente. Determinação de proteína foi feita para cada extrato, e os resultados apresentados para as cultivares foram para Benitaka 0,56 e 0,64 $\mathrm{mg} / 100 \mathrm{~g}$, Rubi 1,38 e $6,45 \mathrm{mg} / 100 \mathrm{~g}$ e Borbon 21,38 e $5,68 \mathrm{mg} / 100 \mathrm{~g}$, respectivamente. Os extratos foram submetidos a tratamentos térmicos $\left(60^{\circ} \mathrm{C}, 65^{\circ} \mathrm{C}, 70^{\circ} \mathrm{C}\right.$ e $75^{\circ} \mathrm{C}$ para um período de 1 a 10 minutos), observando o comportamento da atividade enzimática da peroxidase e polifenoloxidase, sendo verificada uma diminuição contínua das atividades de peroxidase e de polifenoloxidase diante do tratamento térmico. Os extratos da cultivar Rubi e Benitaka foram mais termoestáveis que o extrato do cultivar Borbon para ambas as enzimas. Porém, as temperaturas usadas não foram suficientes para inativação total das enzimas.

TERMOS PARA INDEXAÇÃO: Peroxidase, polifenoloxidase, atividade, uva, Vitis vinifera.

1. Acadêmicas do Curso de Química - UEM - Maringá, PR.

2. PhD em Ciências de Alimentos - Universidade Estadual de Maringá - Maringá, PR. 


\section{INTRODUCTION}

The largest Brazilian producer of Vitis venifera grapes is the State of Rio Grande do Sul, where the climatic conditions are favorable for the grape cultivation due to the occurrence of both rigorous winter, which makes the plant vegetative rest possible, and summer brightness, which promotes a full fructification (Amarante, 1986).

The State of Paraná has recently been pointed as an economic support for having implanted new juice factories in the Northern area of the state. One of the problems faced by the juice factories is the oxidative enzymes. The undesirable change in the colour, flavour and texture of fruits and vegetables is associated with the enzymes polyphenoloxidase (EC 1.10.3.1; PPO) and peroxidase (EC 1.11.1.7; POD) of the oxiredutase group (Reed, 1975; Clemente \& Pastore, 1998). POD and PPO can provide a great and varied number of reactions, and for this reason they exhibit one of the largest versatility degrees than any other enzyme. They are able to catalyse a great number of oxidation reactions in plants (McLellan \& Robinson, 1984). It is known that the grapes containing a high amount of those enzymes (PPO and POD) can suffer with oxidative reactions, causing a fast darkening when these grapes are squeezed for juices or wine production, and this decreases the quality of the final product (Oliveira et al., 1994). In damage berries an unpleasant flavour and loss of the colour can also be developed, which will interfere in the quality of the final product. Therefore, it is important to control the PPO and POD effect, as well as to establish their characteristics associated to the fruit. The fruits enzymatic darkening is a result of the catalytic oxidation of certain phenol compounds naturally found in the fruits. The oxidation of phenolic compounds in recently squeezed grape juices interferes in the coloration and flavour of the grape juice, resulting in a lower quality wine. Although peroxidase and polyphenoloxidase are involved with the enzymatic oxidation of the grape juice, the polyphenoloxidase is the main responsible enzyme for that oxidation (Cash et al., 1976; Valero et al., 1988, Yokotsuka et al., 1991). However, the peroxidase observed in superior plants is recognized as one of the most stable enzymes regarding the thermal treatment (Clemente, 1998).

It is known that under certain thermal treatment (HTST) conditions, POD can have its activity regenerated, which contributes to both the flavor loss and the unpleasant flavors development (Lu \& Whitaker, 1974; Clemente \& Robinson, 1995).
In the present study the enzymatic activity of the peroxidase and polyphenoloxidase extracted from the grape pulp and peel was evaluated, as well as the effect of thermal treatment on the activity of these enzymes.

\section{MATERIALS AND METHODS}

The Grape Cooperative from Marialva city, state of Paraná, supplied the fresh and ripe Rubi, Benitaka and Bourbon grapes cultivars used in the experiment. All chemical reagents used were of analytical grade, obtained from BDH Light Laboratories Ltd.

\section{Peroxidase and polyphenoloxidase extracts preparation}

The grapes were washed with distilled water, then the peel was separated from the pulp and the seeds were discarded. $50 \mathrm{~g}$ of peel and $300 \mathrm{~g}$ of pulp of each cultivar were weighed, then each sample was homogenized for 1 minute in $100 \mathrm{~mL}$ of cold sodium phosphate buffer (100 mM, pH 6.0), using a Warning blender. The resulting suspension in phosphate was centrifuged at $17,000 \mathrm{~g}$ for 20 minutes at $4 \mathrm{C}$. The supernatant designated as soluble enzymatic extract was collected and stored at $-18^{\circ} \mathrm{C}$. To obtain the extract of the ionically bound enzymes, the residue remaining after the extraction of soluble fraction, was resuspended in $100 \mathrm{~mL}$ of $\mathrm{NaCl}(4 \mathrm{~g})$ solution in sodium phosphate buffer $(100 \mathrm{mM}, \mathrm{pH} 6,0)$, and centrifuged at 17,000 $\mathrm{g}$ for 20 minutes at $4 \mathrm{C}$. The supernatant fluids were collected and stored at $-18^{\circ} \mathrm{C}$, and the centrifugation in the same previous conditions was made soon afterwards. Subsequently, the supernatant containing the soluble fraction and the ionically bound fraction were mixed and stored at $-18^{\circ} \mathrm{C}$. This proceeding was carried out for both peel and pulp of each cultivar.

The protein precipitation in the extracts from peel and pulp were carried out using cold acetone in the proportion of 1: 4 .

\section{Protein Determination}

The protein determination in the concentrated enzymatic extracts was carried out according to the method described by Bradford (1976).

\section{POD and PPO enzymatic activity determination}

A spectrophotometer was used (Hitachi U2000) for the peroxidase enzymatic activity determination $(\lambda=460 \mathrm{~nm})$ according to the method de-

Ciênc. agrotec., Lavras. V.27, n.3, p.635-642, maio/jun., 2003 
scribed by Clemente (1998). For determining the polyphenoloxidase activity $(\lambda=420 \mathrm{~nm})$, a modification of the method described by Siddiq et al. (1992) was used. The standard reaction mixture consisted of $3.4 \mathrm{~mL}$ of $100 \mathrm{mM}$ sodium phosphate buffer ( $\mathrm{pH}$ 6.0); $0.4 \mathrm{~mL}$ of cathecol; $0.2 \mathrm{~mL}$ of enzyme extract. An enzymatic activity unity was defined with the increase of an absorbance change unit per minute, as much as for the peroxidase as for polyphenoloxidase. Each sample was assayed in triplicate.

\section{Thermal treatment}

The heating effect on the grapes' crude extracts was carried out at $60^{\circ} \mathrm{C}, 65^{\circ} \mathrm{C}, 70^{\circ} \mathrm{C}$ and $75^{\circ} \mathrm{C}$ during 1 to 10 minutes. $0.5 \mathrm{~mL}$ of crude extract was pipetted into small Pyrex test tubes $(5 \mathrm{~mL}$ and wall thickness $1.0 \mathrm{~mm}$ ) previously equilibrated in a thermostatic water bath to the required temperature. The test tubes were stoppered with glass marbles to prevent evaporation. At the end of each time the test tubes were removed and put into ice bath for the subsequent PPO and PDO enzymatic activity determination.

\section{RESULTS AND DISCUSSION}

The results of POD, PPO and protein concentration activities in the assayed cultivars are shown in the Table 1.
The protein concentrations present in the peel and pulp of the three cultivars were shown to be different, the Borbon cultivar peel showing a higher protein concentration when compared with the other cultivars. The POD and PPO enzymatic activities measurements before the thermal treatment revealed the presence of POD in the Rubi and Benitaka cultivar peels. The Benitaka peel extract showed a higher enzymatic activity for POD, 30 times higher when compared to the other two cultivars peel extracts. The values found for PPO activity in the Rubi and Benitaka pulp extracts were superior to those obtained in the peel extract. The result of the PPO activity in the Borbon peel was approximately 5 times superior to the other analyzed cultivars.

Thermal treatment caused a continuous decrease in the POD and PPO activities as the temperature increased from $60^{\circ}$ to $75^{\circ} \mathrm{C}$, both to pulp and peel extracts of all cultivars, which is in agreement with what was reported by Khan \& Robinson (1993) and Valero et al (1988).

In Figures 1 to 4, it can be observed that the POD enzymatic activity suffered a decline with the increase of temperature and time. However, the time interval and temperatures analyzed were not enough for a total enzyme activity inactivation. According to Valderrama et al (2001) this behavior with peroxidase from apple reported by the studies is due to the presence of different isoenzymes. They believe that this isoenzymes can also be found in the Rubi, Benitaka and Borbon grapes cultivars.

TABLE 1 - Grape protein concentration $(n=3)$, peroxidase and polyphenoloxidase activity on grapes.

\begin{tabular}{ccccc}
\hline \multicolumn{2}{c}{ Sample } & \multicolumn{1}{c}{$\begin{array}{c}\text { Protein } \\
(\mathbf{m g} / \mathbf{1 0 0} \mathbf{g}) \pm \boldsymbol{\delta}\end{array}$} & $\begin{array}{c}\text { POD activity } \\
\text { units/100 } \mathbf{g} \pm \boldsymbol{\delta}\end{array}$ & $\begin{array}{c}\text { PPO activity } \\
\text { units/100 g } \pm \boldsymbol{\delta}\end{array}$ \\
\hline \multirow{2}{*}{ Rubi } & Peel & $1.38 \pm 0.02$ & $53.00 \pm 0.01$ & $17.40 \pm 0.01$ \\
\cline { 2 - 5 } & Pulp & $6.45 \pm 0.01$ & $7.67 \pm 0.01$ & $60.40 \pm 0.01$ \\
\hline \multirow{2}{*}{ Borbon } & Peel & $21.38 \pm 0.02$ & $11.50 \pm 0.01$ & $102.60 \pm 0.03$ \\
\cline { 2 - 5 } & Pulp & $5.68 \pm 0.01$ & $141.11 \pm 0.03$ & $100.18 \pm 0.02$ \\
\hline \multirow{2}{*}{ Benitaka } & Peel & $0.56 \pm 0.01$ & $327.00 \pm 0.02$ & $26.20 \pm 0.01$ \\
\cline { 2 - 5 } & Pulp & $0.64 \pm 0.01$ & $44.00 \pm 0.01$ & $48.62 \pm 0.01$ \\
\hline
\end{tabular}

\section{$\mathbf{n}=$ number of repetition}

$\delta=$ standard deviation 


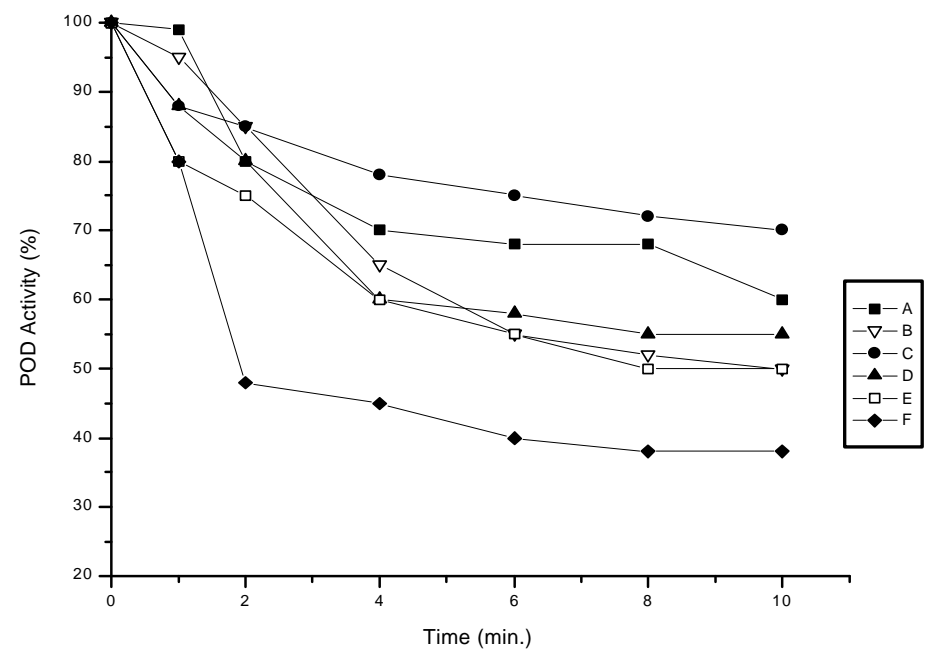

FIGURE 1 - Peroxidase activity in the grape cultivars extracts (A) Rubi pulp, (B) Rubi peel, (C) Benitaka pulp, (D) Benitaka peel, (E) Borbon pulp and (F) Borbon peel, after heat treatment at $60^{\circ} \mathrm{C}$.

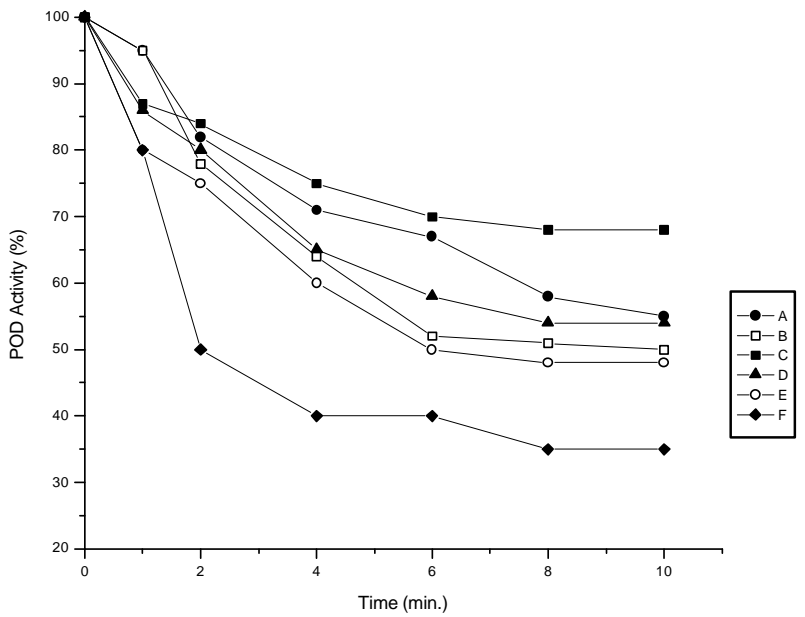

FIGURE 2 - Peroxidase activity in the grape cultivars extracts (A) Rubi pulp, (B) Rubi peel, (C) Benitaka pulp, (D) Benitaka peel, (E) Borbon pulp and (F) Borbon peel, after heat treatment at $65^{\circ} \mathrm{C}$. 


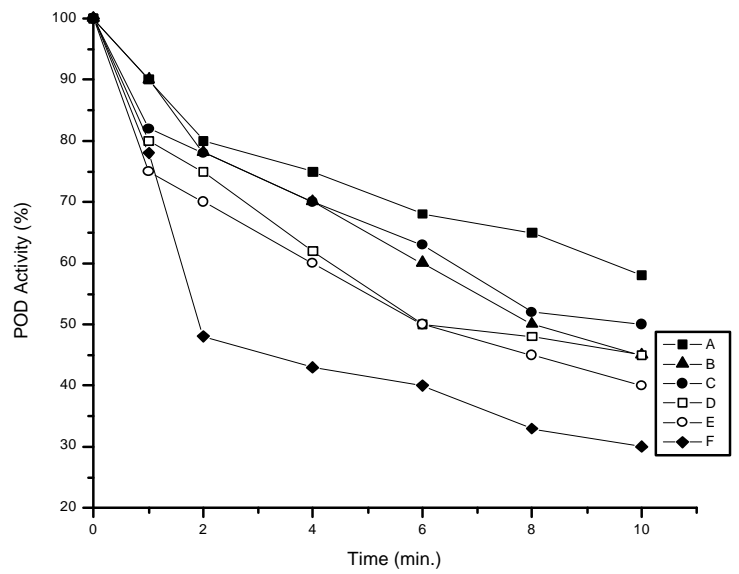

FIGURE 3 - Peroxidase activity in the grape cultivars extracts (A) Rubi pulp, (B) Rubi peel, (C) Benitaka pulp, (D) Benitaka peel, (E) Borbon pulp and (F) Borbon peel, after heat treatment at $70^{\circ} \mathrm{C}$.

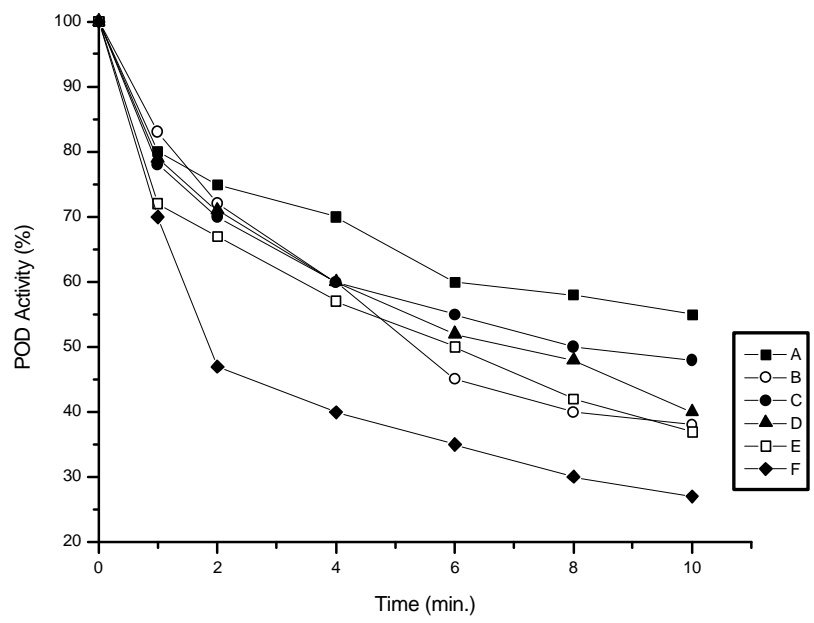

FIGURE 4 - Peroxidase activity in the grape cultivars extracts (A) Rubi pulp, (B) Rubi peel, (C) Benitaka pulp, (D) Benitaka peel, (E) Borbon pulp and (F) Borbon peel, after heat treatment at $75^{\circ} \mathrm{C}$.

For POD activity after six minutes of heating, the Borbon cultivar peel extract presented an activity decrease of $58 \%$ at $60 \mathrm{C}$, and $65 \%$ of the activity at $75^{\circ} \mathrm{C}$. In the pulp extract the activity decreased $45 \%$ when the heating temperature was $60^{\circ} \mathrm{C}$, and $52 \%$ at $75^{\circ} \mathrm{C}$. The Rubi and Benitaka cultivars extracts presented an enzymatic activity decline variation similar to the POD, and less activity as well, when compared to the Borbon cultivar extract. That behavior suggested the presence of isoenzymes in the Rubi and Benitaka cultivars which are more heat stable. Among the extracts evaluated, the Borbon cultivar extract showed a higher decline of the POD and PPO activities when submitted to the temperatures of $60,65,70$ and $75^{\circ} \mathrm{C}$.

The PPO activity can be observed in figures 5 to 8. It showed a similar decline as the POD when the temperature increased from $60^{\circ} \mathrm{C}$ to $75^{\circ} \mathrm{C}$, however, when the temperature went up to $75^{\circ} \mathrm{C}$ and the heating time increased, the PPO activity decreased, though a total inactivation was not achieved. 


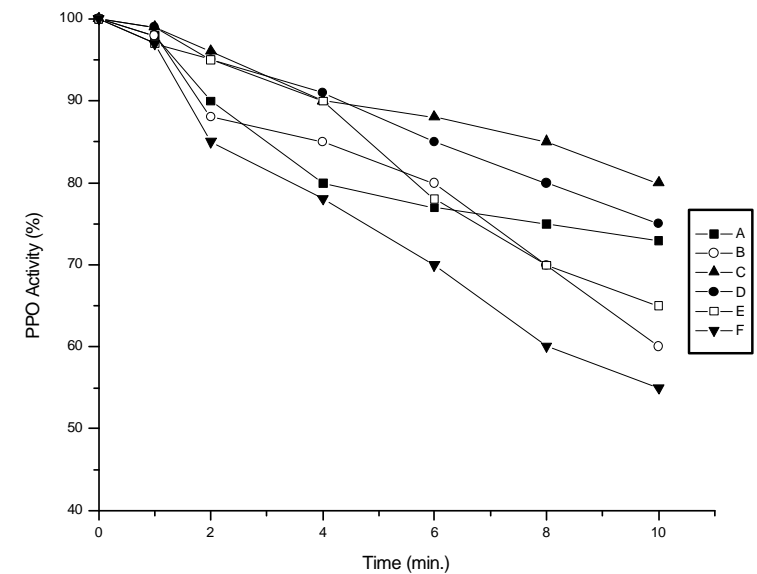

FIGURE 5 - Polyphenoloxidase activity in the grape cultivars extracts (A) Rubi pulp, (B) Rubi peel, (C) Benitaka pulp, (D) Benitaka peel, (E) Borbon pulp, and (F) Borbon peel after heat treatment at $60^{\circ} \mathrm{C}$.

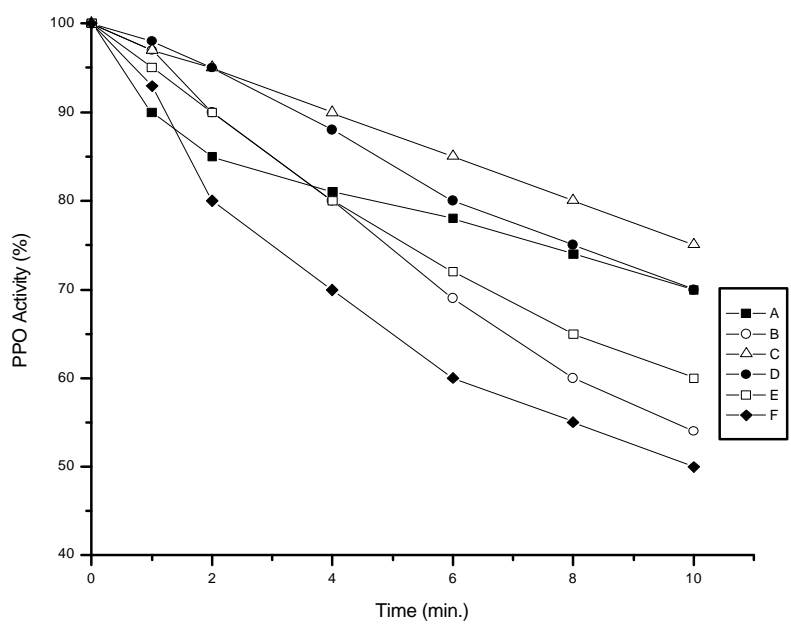

FIGURE 6 - Polyphenoloxidase activity in the grape cultivars extracts (A) Rubi pulp, (B) Rubi peel, (C) Benitaka pulp, (D) Benitaka peel, (E) Borbon pulp and (F) Borbon peel, after heat treatment at $65^{\circ} \mathrm{C}$.

For a 10 minutes time period of heating the PPO activity for the pulp and peel of all cultivars showed a decline of enzyme activity. In the cultivar peel fractions analyzed it was observed a higher decline of the enzymatic activity for PPO extracted from Borbon cultivar, presenting, in a 10 minutes time period of heating a decrease of $55 \%$ of the activity at $65^{\circ} \mathrm{C}$ and $70 \%$ at $75^{\circ} \mathrm{C}$. The results are similar to what was reported by Valero et al. (1988) However, the temperatures $\left(60,65,70\right.$ and $\left.75^{\circ} \mathrm{C}\right)$ and heating periods (1 to 10 min) used were not enough for a total inactivation of the enzymes. The POD and PPO enzymatic activity had a variation among the cultivars used in the experiment. In the Borbon cultivar extract (used in the wine production) those activities presented a larger decline when submitted to temperatures of 60,65 , 70 and $75^{\circ} \mathrm{C}$, and for heating periods from 1 to 10 min. However, that remaining enzyme activity can

Ciênc. agrotec., Lavras. V.27, n.3, p.635-642, maio/jun., 2003 
develop desirable flavor in the wine. The isoenzymes isolation and the characterization can be of great importance to obtain more information regarding that oxidative enzymes inactivation process.

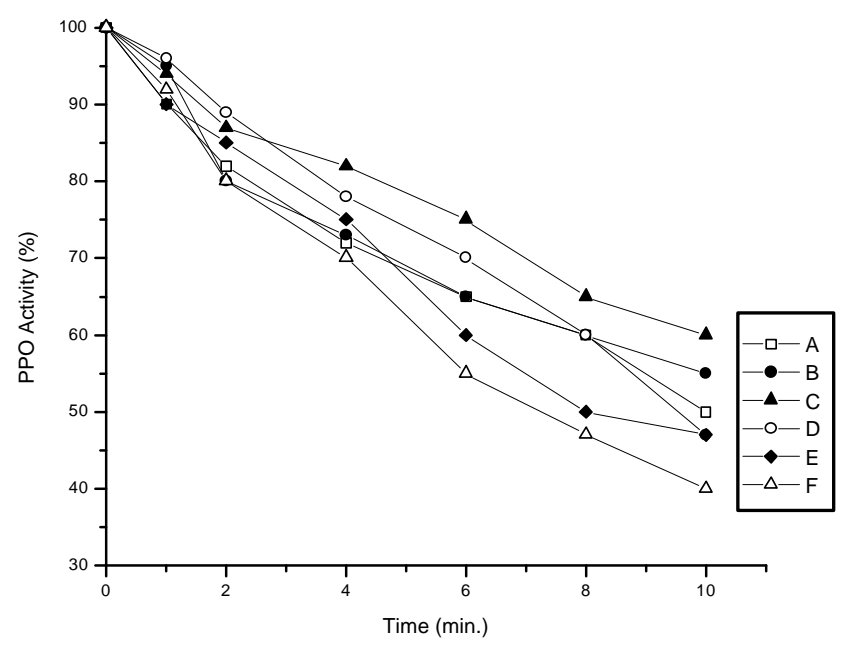

FIGURE 7 - Polyphenoloxidase activity in the grape cultivars extracts (A) Rubi pulp, (B) Rubi peel, (C) Benitaka pulp, (D) Benitaka peel, (E) Borbon pulp and (F) Borbon peel, after heat treatment at $70^{\circ} \mathrm{C}$.

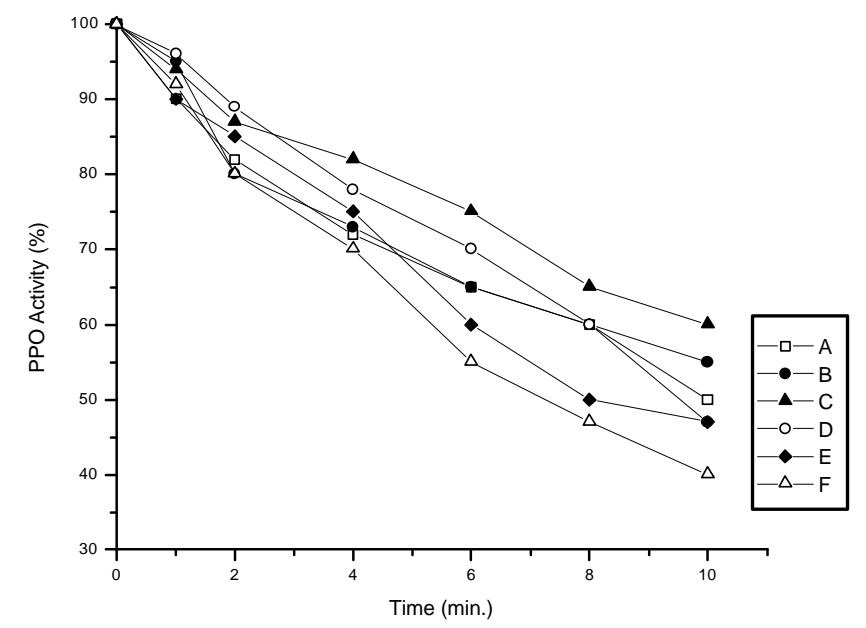

FIGURE 8 - Polyphenoloxidase activity in the grape cultivars extracts (A) Rubi pulp, (B) Rubi peel, (C) Benitaka pulp, (D) Benitaka peel, (E) Borbon pulp and (F) Borbon peel, after heat treatment at $75^{\circ} \mathrm{C}$. 


\section{ACKNOWLEDGEMENT}

To the CNPq for the IC scholarship.

\section{REFERENCES}

AMARANTE, J. O. A. Vinhos e vinícolas do Brasil. São Paulo: Editorial Ltda., 1986.

BRADFORD, M. M. A rapid and sensitive method for the quantitation of microgram quantities of protein utilizing the principle of protein - dye binding. Analytical Biochemistry, San Diego, v. 72, n. 1-2, p. 248-254, 1976.

CASH, J. N.; SISTRUNK, W. A.; STUTTE, C. A. Characteristics of concord grape polyphenoloxidase involved in juice color boss. Journal of Food Science, Chicago, v. 41, p. 1398-1402, 1976.

CLEMENTE, E.; PASTORE, G. M. Peroxidase and polyphenoloxidase, the importance for food technology. Ciência e Tecnologia Alimentos, Campinas, v. 32, p. 167-171, 1998.

CLEMENTE, E.; ROBINSON, D. S. The termostability of purified oranges isoperoxidase. Arquivos de Biologia e Tecnologia, Campinas, v. 38, p. 1109-1118, 1995.

CLEMENTE, E. Purification and thermostability of purified isoperoxidases from Oranges. Phytochemistry, Oxford, v. 49, n. 1, p. 29-36, 1998.

KHAN, A. A.; ROBINSON, D. S. The thermostability of purified mango isoperoxidase. Food Chemistry, Barking, v. 47, p. 53-59, 1993.

LU, A. T.; WHITAKER, J. R. Some factors affecting rats of heat inactivation and reactivation of horseradish peroxidase. Journal of Food Science, Chicago, v. 39, p. 1173-1178, 1974.

McLELLAN, K. M.; ROBINSON, D. S. Heat stability of peroxidase from orange. Food Chemistry, Barking, v. 13, p. 139-147, 1984.

OLIVEIRA, S. L.; GUERRA, N. B.; MACIEL M. I. S.; OLIVERA, A. V. S. Polyphenoloxidase activity, polyphenols concentration and browning intensity during soursops (Annona muricata, L.) maturation. Journal of Food Science, Chicago, v. 59, p. 1050-1052, 1994.

REED, G. Oxireductases In: Enzymes in food processing. New York: Academic Press, 1975.

SIDDIQ, M., SINHA, N. K., CASH, J. N. Characterization of polyphenoloxidase from stanley plums. Journal of Food Science, Chicago, v. 57, n. 5, p. 11771179, 1992.

VALDERRAMA, P., MARANGONI, F., CLEMENTE, E. Efeito do tratamento térmico sobre a atividade de peroxidase (POD) e polifenoloxidase (PPO) em maçã (Mallus comunis). Ciência e Tecnologia de Alimentos, Maringá, v. 21, n. 3, p. 257-342, 2001.

VALERO, E.; VARÓN, R.; CARMONA, G. F. Characterization of polyphenoloxidaserom airen grape. Journal of Food Science, Chicago, v. 53, n. 5, p. 1482$1485,1988$.

YOKOTSUKA, K.; SHIMIZU, T.; SHIMIZU, T. Polyphenoloxidase from six mature grape varieties and their activities towards various phenols. Journal of Fermentation and Bioengineering, Osaka, v. 71, p. 156-162, 1991. 